\title{
Ultrasound Trilaminar Sign of Abdominal Cocoon
}

\author{
Venkatraman Indiran ${ }^{\mathrm{a}}$ Dillibabu Ethiraj ${ }^{\mathrm{b}}$ \\ ${ }^{\text {a }}$ Department of Radio-diagnosis, Sree Balaji Medical College and Hospital, Chennai, India; ${ }^{\text {b}}$ Department of Radio- \\ diagnosis, Bhaarath Medical College and Hospital, Chennai, India
}

Keywords

Cocoon $\cdot$ Ultrasound

\section{Sinal trilaminar ecográfico do casulo abdominal}

\section{Palavras Chave}

Casulo $\cdot$ Ultrassom

A 50-year-old male presented with vomiting and abdominal pain for 3 days. He is a known case of chronic renal failure for the past 2 years undergoing repeated peritoneal dialysis. On physical examination, his abdomen was distended. Laboratory investigation showed increased serum creatinine levels $\sim 6 \mathrm{mg} / \mathrm{dL}$. Ultrasound abdomen showed shrunken kidneys with increased cortical echoes and ascites. Apart from that, thickened peritoneum or a membrane overlying the bowel loops was seen on high-frequency ultrasound as a triple-layer appearance, which is called "ultrasound trilaminar sign" (Fig. 1a, b) [1]. The "ultrasound trilaminar sign" is considered characteristic of the abdominal cocoon or encapsulating peritoneal sclerosis (EPS) [2]. EPS is characterized by

karger@karger.com www.karger.com/pjg

Karger"

BOPEN ACCESS

\section{(c) 2021 Sociedade Portuguesa de Gastrenterologia} Published by S. Karger AG, Basel

This is an Open Access article licensed under the Creative Common Attribution-NonCommercial-4.0 International License (CC BY-NC) (http://www.karger.com/Services/OpenAccessLicense), applicable to the online version of the article only. Usage and distribution for commercial purposes requires written permission. clustered small bowel loops with narrow base and surrounding thick fibro-collagenous membrane. It may be idiopathic or secondary to repeated peritoneal dialysis, abdominal tuberculosis, abdominal surgeries, and drugs like propranolol $[1,3]$. The three layers forming the ultrasound trilaminar appearance are the superficial hyperechoic peritoneal membrane, a middle hypoechoic layer of the bowel wall, and the deep hyperechoic layer produced by the bowel gas or contents [1]. This trilaminar appearance is not to be confused with computed tomography trilaminar sign, which represents submucosal bowel edema [1]. Presence of ascites is usually essential for identifying the trilaminar appearance and cauliflowerlike appearance of clustered bowel loops. The patient was advised surgical evaluation for removal of membrane and adhesiolysis.

\section{Statement of Ethics}

All procedures performed in studies involving human participants were in accordance with the ethical standards of the institutional and/or national research committee and with the $1964 \mathrm{Hel}-$ sinki Declaration and its later amendments or comparable ethical standards. 
Fig. 1. a Ultrasound abdomen shows clumped bowel loops (white arrow) and ascites. b Ultrasound trilaminar sign of abdominal cocoon hyperechoic membrane (white arrow), hypoechoic bowel wall (arrowhead), and hyperechoic bowel contents (black arrow).
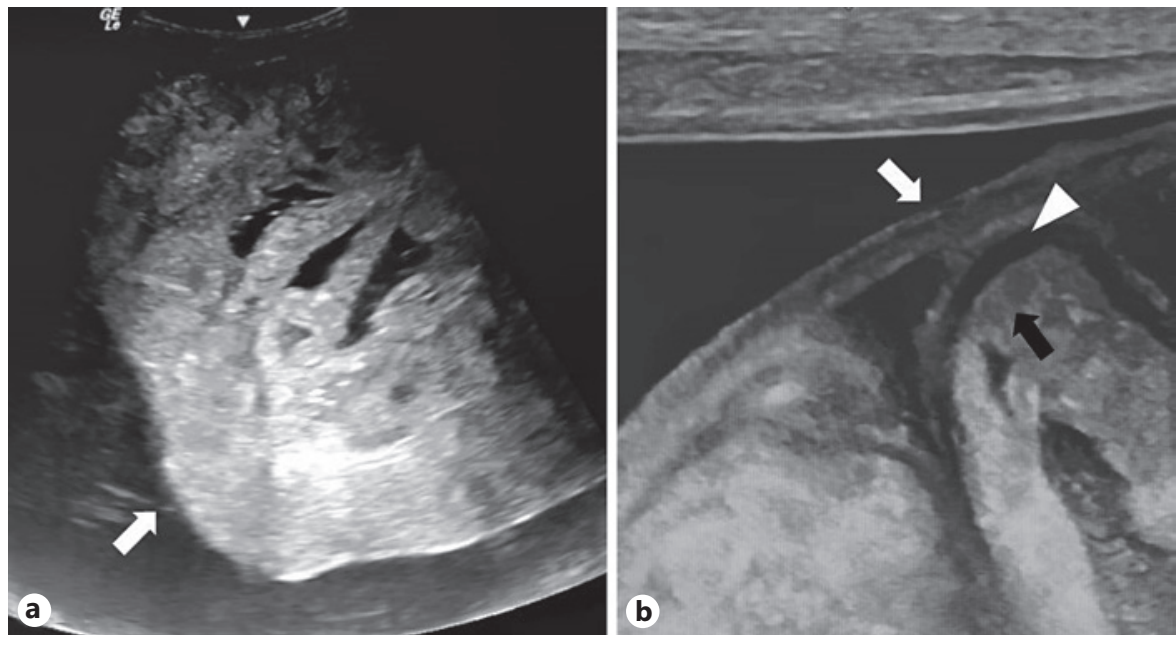

\section{Conflict of Interest Statement}

The authors declare that they have no conflict of interest. Informed consent was obtained from the individual participant included in the study.

\section{Funding Sources}

There is no funding.

\section{Author Contributions}

Substantial contributions to the conception or design of the work; or the acquisition, analysis, or interpretation of data for the work - D.E., V.I. Drafting the work or revising it critically for important intellectual content - D.E., V.I. Final approval of the version to be published - D.E., V.I. Agreement to be accountable for all aspects of the work in ensuring that questions related to the accuracy or integrity of any part of the work are appropriately investigated and resolved - D.E., V.I.

\section{References}

Ultrasound Trilaminar Sign of Abdominal Cocoon
1 Singhal M, Krishna S, Lal A, Narayanasamy S, Bal A, Yadav TD, et al. Encapsulating Peritoneal Sclerosis: The Abdominal Cocoon. Radiographics. 2019 JanFeb;39(1):62-77.

2 Campbell S, Clarke P, Hawley C, Wigan M, Kerlin P, Butler J, et al. Sclerosing peritonitis: identification of diagnostic, clinical, and radiological features. Am J Kidney Dis. 1994 Nov;24(5):819-25.

3 Ethiraj D, Indiran V. V Indiran - Abdominal Cocoon: "Cauliflower Sign" on Contrast-Enhanced Computed Tomography Scan. GE Port J Gastroenterol. 2021;28(1):76-8. 